\title{
TESTING FOR CONTAGION IN ECONOMIC LITERATURE
}

\author{
Ceren Kocabas *
}

* Akdeniz University, Antalya, Turkey

Contact details: Akdeniz University, Dumlupınar Boulevard, 07058 Campus, Antalya, Turkey

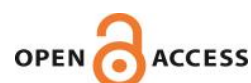

How to cite this paper: Kocabas, C. (2019). Testing for contagion in economic literature. Journal of Governance \& Regulation, 8(3), 42-46.

http://doi.org/10.22495/jgr_v8_i3_p3

Copyright $@ 2019$ The Authors

This work is licensed under a Creative Commons Attribution 4.0 International License (CC BY 4.0).

https://creativecommons.org/licenses/by/ $\underline{4.0 /}$

ISSN Print: 2220-9352

ISSN Online: 2306-6784

Received: 27.05.2019

Accepted: 23.07 .2019

JEL Classification: F30, F60, F65, G DOI: 10.22495/jgr_v8_i3_p3

\begin{abstract}
The contagion of the financial crisis is an unavoidable fact for the economies of the global system anymore. Therefore measuring contagion, analyzing the propagation of volatility across countries became mainly important research topics among economists. There are many different econometric techniques used to test for contagion effect of financial crises. Transmission of shocks from one country to another can be calculated with four different techniques. The empirical literature mostly based on the techniques of measuring cross-market correlations, GARCH models, cointegration and probit models. In these models, economists use financial or real indicators or both of them in their analyses. As the financial indicators, they generally use share price indices, interest rates, exchange rates, and inflation rate. As the real indicators, they generally use the values of GDP, imports, exports, unemployment rate, etc. The aim of this paper is to underline the prominent empirical studies in the field of contagious crises.
\end{abstract}

Keywords: Contagion, Financial Contagion, Economic Crises, Economic Globalization

Authors' individual contribution: the author is responsible for all the contributions to the paper according to CRediT (Contributor Roles Taxonomy) standards.

\section{INTRODUCTION}

The models of contagious crises mostly appeared after the 1990s, and increased in number especially after the Asian crisis. The world economy faced with the 1987 American stock market crisis, the 1980s Latin American crises, the 1992 European Monetary System Crisis, the 1994 Mexican crisis, the 1997 Asian crisis, the 1998 Russian crisis, the 2008 crisis, and the European debt crisis respectively. Recently in 2018, the Turkish currency and debt crisis emerged in Turkey. Economies of the new era suffer from economic shocks and their spill-over effects across countries. It is clear that the contagion effect is inevitable for an economy which is connected to other world economies by financial or real linkages. So, the models of contagious crises have now an important place in economic literature.

This paper is a comprehensive look at the empirical studies on measuring contagion. The discussion was on the techniques and methods which were primarily used in literature. It is important to be able to see the big picture. It is clear that the contagion effect is inevitable for an economy which is connected to other world economies by financial or real linkages. So, the models of contagious crises have now an important place in economic literature.

In this article, Section 2 provides the literature review on new economic thoughts and empirical studies on testing for contagious crises. In Section 3 the correlation analysis on measuring contagion was discussed. Section 4 explores testing contagion by ARCH-GARCH models. The empirical studies using cointegration technique to measure contagion were discussed in Section 5 and testing for contagion effect by probit models was discussed in Section 6 . The last section presents a conclusion of the paper.

\section{LITERATURE REVIEW}

The new literature made an appearance mainly in the second half of the 1990s. Some of the leading economists of this new economic thought are Krugman, Alejandro and Velasco, King and Wadhwani, Mishkin, Obstfeld, McKinnon and Pill, Goldfajn and Valdes, Gerlach and Smeths, Glick and Rose, Sachs, Radalet, Miller, Calvo, Kaminsky, Fratzscher, Corsetti, Forbes and Rigobon, Chang, Protasi, Caramazza and Mankiw. The main research 
topics in new literature models are early warning systems, contagion effect, financial fragility, contagion channels, globalization of financial markets, the contagious crises such as the Mexican crisis and the Asian crisis, speculative movements, investors expectations and the problems in the banking sector.

On the empirical side, the experimental analyses gathered pace in the last years on measuring for the contagion effect of financial crises. In this field, we can see the leading analyses of King and Wadhwani, Calvo and Reinhart, Loretan and English, Forbes and Rigobon, Corsetti, Hamao, Edwards, Fleming, and Lopez, Khalid and Rajaguru, Chiang et al., Sun and Zhang, Kogid et al. and Kuusk et al., Gentile and Giordino, and Azad, Eichengreen et al., Kruger et al., Eichengreen and Rose, Glick and Rose, Caramazza et al., Novo, and Haile and Pozo. Recent studies on contagion contain correlation analyses and ARCH-GARCH models such as the models of Cominetta (2016), Mohti, Dionisio, Ferreira, and Vieira (2019), and Zhanyun (2018). Zhanyun's analysis depended on spatial autocorrelation model. Cominetta's model was a stable linear correlation model. There are also few analyses of economists based on other different techniques such as copula models (Mohti et al., 2019), Markov perfect equilibrium (Grant, 2016) or systemic stress test (Cont et al., 2017). Mohti, Dionisio, Ferreira, and Vieira (2019) applied ARMAGARCH technique beside copula models to test for contagion.

\section{TESTING FOR CONTAGION BASED ON CORRELATION COEFFICIENTS}

Testing the significance of correlation coefficients between markets are the easier and most understandable tests of all. These tests, first of all, calculate the correlation between two markets in the steady period, then calculate the increase in correlation coefficients after a shock encountered. If a correlation coefficient shows a significant increase, this means that the transmission mechanism between two markets increases and contagion occurs after an emerging shock. Most of the concerning studies on contagion which applies correlation analysis were the discussions of contagion effect which emerged after the collapse of the US Stock Market in 1987.

King and Wadhwani (1990) used hourly data between 1987 and 1988. The key indicators were share price indices. The United Kingdom, the USA, and Japan were the countries analyzed. They applied correlation analysis to test for contagion. It was observed that there was an increase in correlation between markets after the crisis, and contagion occurred (pp. 5-33).

Calvo and Reinhart (1996) used weekly data for the year 1994. The key indicators were share price indices. They analyzed 6 Asian and 7 Latin American countries. Their test based on correlation coefficients. In conclusion, they observed that the estimated correlation coefficients were biased upward. Markets are more volatile. There was a substantial increase in correlation in share prices and Brady bonds across emerging markets of Asia and Latin America (pp. 10-17).
Loretan and English (2000) used daily data from 1992 to 2000. They estimated the independent variables of long-term interest rate, share price indices and exchange rates for Germany and England. Their test based on correlation coefficients. They concluded that there was a considerable increase in correlation between markets following the 1994 Mexican crisis, and contagion occurred.

Forbes and Rigobon (2002) used daily data from 1996 to 1997, from 1993 to 1995, and from 1986 to 1987 in their analyses. The key indicators were share price indices. They observed 28 countries from different parts of the world. They measured the correlation between these relevant markets. It was observed that the contagion test based on the correlation coefficients was under the effect of heteroscedasticity (inconstancy of variance), and for this reason, correlation coefficients were not biased upward, no significant increase happened in crossmarket correlation during the Asian crisis, the Mexican crisis and the collapse of 1987 US markets. So, the contagion did not occur. They asserted that such crises were the results of interdependence, not the contagion (pp. 2223-2261).

Corsetti, Pericoli, and Sbracia (2005) used daily data for the year of 1997. The key indicators were share price indices. Indonesia, Korea, Malaysia, Philipines, Singapore, Thailand, Russia, Argentina, Brasil, Mexico, and G7 countries were the markets observed. They applied correlation analysis for measuring contagion. They found evidence of contagion from Hong Kong to Singapore, Philippines, France, Italy and the United Kingdom (pp. 1177-1199).

Recently, Cominetta (2016) and Zhanyun (2018) made analyses on contagion and used correlation coefficients for the measurement. Zhanyun's analysis depended on a spatial autocorrelation model. Cominetta's model was a stable linear correlation model.

\section{TESTING FOR CONTAGION BY ARCH-GARCH}

The second method for testing the contagion effect is $\mathrm{ARCH}$ and GARCH analyses. They are used to calculate the transmission mechanism of variancecovariance between countries. The variations in variance matrices are observed.

Hamao, Masulis, and Ng (1990) used share price indices as the independent variables. The data was the daily data from 1985 to 1988. The markets of the USA, the United Kingdom, and Japan were observed. They applied GARCH-M method to test for contagion. They found evidence of contagion. The volatility propagation effect was significant from the USA and the United Kingdom to Japan (pp. 281-307).

Edwards (1998) used weekly data from 1990 to 1998. The independent variable was short term interest rate and the markets of Argentina, Mexico and Chile were observed. He applied the augmented GARCH method to measure contagion. He concluded that the contagion occurred from Mexico to Argentina, however, contagion did not occur from Mexico to Chile.

Fleming and Lopez (1999) used daily data from 1992 to 1994 . The independent variables were the interest rates of 5 years government bonds and the observed countries were the USA, the United Kingdom, and Japan. They applied the GARCH $(1,1)$ 
method to test for contagion. In conclusion, they found that there was evidence of propagation of volatility from New York towards Tokyo and London markets. In other words they found evidence of contagion, however, there was no evidence of propagation of volatility towards New York Stock Market.

Khalid and Rajaguru (2006) used daily data from 1994 to 1999. The estimated variables were exchange rates. They analyzed the markets of India, Indonesia, Japan, Korea, Malaysia, Pakistan, Philipines, Singapore, Taiwan, and Thailand. They applied the MGARCH method for measuring contagion. They compared the conditions of markets before the crisis and after the crisis. They found evidence of an increase in the linkages between Asian currency markets during the periods before the crisis and after the crisis. In other words, contagion occurred, however, these linkages between relevant markets were weak during the period before the crisis.

Chiang, Jeon, and Li (2007) used daily data from 1990 to 2003. The independent variables were share price indices. They observed the markets of Thailand, Malaysia, Indonesia, Philipines, Korea, Taiwan, Hong Kong, Singapore, Japan, and the USA. They applied the DCC-GARCH method to test for contagion. As the result of their analysis, the large part of the coefficients of variance equation was significant. The contagion effect was observed (pp. 1206-1228).

Sun and Zhang (2009) used daily and monthly data from 2005 to 2008 and from 2007 to 2008. The independent variables were share price indices, inflation rate, trade balance et al. They applied the MGARCH and UGARCH method to test for contagion. They observed the markets of USA, China, and Hong Kong for the MGARCH and the markets of China and Hong Kong for the UGARCH. They found that there was evidence of contagion from the USA to China and Hong Kong in the MGARCH analysis. There was no evidence of contagion in the UGARCH analysis.

Kogid, Ching, and Jusoh (2009) used daily data from 1997 to 2000. They examined the movements of exchange rates. They observed the markets of Thailand, Singapore, Korea, and Malaysia. They applied the GJR-GARCH method to test for contagion effect. They concluded that contagion occurred from Thailand, Singapore, and Korea to Malaysia (pp. 128-138).

Kuusk, Paas, and Viikmaa (2011) used daily data from 2008 to 2009. They estimated share price indices as the indicators. They observed the stock markets of the USA, Estonia, Latvia, and Lithuania They applied the GARCH-M method to test for contagion. They suggested that there was no propagation of the volatility from the USA to Estonia, Latvia, and Lithuania (pp. 61-76).

Mohti, Dionisio, Ferreira, and Vieira (2019) analyzed the contagion effect recently and applied the ARMA-GARCH technique besides copula models to test for contagion.

\section{TESTING FOR CONTAGION BY COINTEGRATION METHOD}

The third test for testing contagion is cointegration method. This method focuses on the variations of long term relations between countries after a shock instead of the variations in the short term. It tests the variations in cointegration vectors in asset market instead of variance-covariance matrices.

Azad (2009) used daily data which were from 1996 to 2006. The key indicators were share price indices. He observed the markets of China, Korea, and Japan. He applied the cointegration test to measure contagion. He found evidence of contagion in three Asian countries (pp. 93-118).

Gentile and Giordino (2012) used daily data which were from 2003 to 2012. The key indicators were share price indices and long term interest rates. They analyzed the markets of France, Germany, Irland, Italy, Portugal, Spain, and the United Kingdom. They applied the cointegration test and granger causality test to test for contagion. They suggested that eurozone countries suffered from the contagion effect initially in the 2008 crisis, and the European debt crisis afterwards (p. 48).

\section{TESTING FOR CONTAGION BY PROBIT MODELS}

The fourth method is the probit models. In the probit models, contagion is analyzed by using the simplified hypothesis, and external facts and the changes in spread mechanism are calculated.

Eichengreen, Rose, and Wyplosz (1996) used quarterly data from 1959 to 1993. The key indicators were the real effective exchange rate, the long-term interest rate, share price indices, inflation rate, exports, imports, unemployment rate etc. They observed the markets of 20 industrialized countries. They applied the probit model to test for contagion. They found the evidence of contagion. They suggested that the countries which were connected by trade could suffer from contagion easier than the countries which had similar macroeconomic conditions.

Kruger, Osakwe, and Page (1998) used yearly data from 1977 to 1993 . The key indicators were the unemployment rate, the inflation rate, M2/reserves etc. They analyzed 19 developed countries. They applied the probit model to test for contagion. They concluded that currency crises could be contagious. There was significant evidence of regional contagion.

Eichengreen and Rose (1999) used quarterly data from 1959 to 1993. They estimated the variables of the inflation rate, the unemployment rate, imports, exports, the long-term interest rate, share price indices, the real effective exchange rate etc. They analyzed 20 industrialized countries. They applied the probit model to test for contagion. As a result, they found evidence of contagion. They suggested that the contagion caused by trade channel could be more predominant than the contagion caused by macroeconomic similarities (pp. 29-56).

Glick and Rose (1999) used yearly data which were the data of 1971, 1973, 1992, 1994 and 1997. The key indicators were the inflation rate, the percentage change in exports, the percentage change in imports etc. They observed 161 countries from different regions of the world. They applied the probit model and T-test to test for contagion. They concluded that currency crises can be regional and currency crises could spread by trade channels (pp. 603-617).

Caramazza, Ricci, and Salgado (2000) used monthly data from 1990 to 1998 . The key indicators 
were the inflation rate, the unemployment rate, the rate of exports to GDP, the real effective exchange rate etc. They observed 41 emerging markets and 20 industrialized countries. They applied the probit model to test for contagion. They suggested that international indicators of financial contagion and financial fragility were highly significant.

Novo (2003) used yearly data which were from 1991 to 1992 . The key indicators were the inflation rate, the real GDP growth rate, M2/international reserves, imports, exports etc. They analyzed the members of G7, EU, NAFTA, APEC which were 65 countries in total. They applied the probit model to test for contagion. They concluded that currency crises were contagious. The currency crisis of 1992 became contagious with the effect of the trade channel.

Haile and Pozo (2008) used quarterly data which were from 1960 to 1998. The key indicators were the inflation rate, the unemployment rate, the real GDP growth rate etc. They observed 37 developed and emerging market economies. They applied the probit model to test for contagion. They concluded that concerning countries suffered from a currency crisis because of unsustainable macroeconomic conditions and contagion. Trade linkages and neighbourhood effect could cause contagion. There was evidence of contagion towards capital markets (pp. 572-588).

\section{CONCLUSION}

Today's economies are more integrated with each other than before in our global economic system. This connection makes the economies of the world more fragile, vulnerable and defenseless to the possible economic shocks. Therefore, the analyses focusing on testing for contagion are increasing day by day. According to the concerning models, the transmission of shocks influence countries by financial channel or trade channel or both. Fratzcher (2002) added a third channel to the literature and called it sunspots, which he referred to the herding behaviour of the international investors. By observing financial indicators, we can see the existence of a financial channel, and by observing real indicators, we can see the existence of the trade channel.

This paper highlighted the outstanding empirical studies of new literature using the main techniques of testing for contagion across markets. The empirical literature on contagion mostly based on the correlation analysis, the GARCH models, the cointegration method and the probit models. Within the framework of this classification, each model for measuring contagion based on different techniques and uses different indicators. In the ARCH-GARCH models, correlation analysis and cointegration tests, economists generally use financial indicators such as share price indices, exchange rates, and interest rates. The inflation rate as a financial indicator is generally used in the probit models. The real (macroeconomic) variables such as the values of GDP, imports, exports, import growth rate, export growth rate, unemployment rate, money supply, etc. are mostly used in the probit models. It is also possible to use macroeconomic variables in the GARCH models to test for contagion.

The leading economists of measuring contagion with correlation coefficients are King and Wadhwani, Calvo and Reinhart, Loretan and English, Forbes and Rigobon, and Corsetti. The leading economists of testing for contagion by the GARCH models are Hamao, Edwards, Fleming and Lopez, Khalid and Rajaguru, Chiang et al., Sun and Zhang, Kogid et al. and Kuusk et al. The leading economists of testing for contagion by cointegration method are Gentile, Giordino and Azad. The leading economists of testing for contagion by the probit models are Eichengreen et al., Kruger et al., Eichengreen and Rose, Glick and Rose, Caramazza et al., Novo, and Haile and Pozo. Some of the recent studies in this field belong to Cominetta (2016), Mohti, Dionisio, Ferreira, and Vieira (2019) and Zhanyun (2018)

Nowadays we can reach many articles of economists studying the financial crises and their contagion effects from different countries. The tests of these economists examined how a crisis in one country increased the probability of a crisis rising in another country. According to these models, crises can not completely be forecasted. Some models did not find the evidence of contagions like the models of Forbes and Rigobon, Edwards, Sun and Zhang, Kuusk, Paas, and Viikmaa. Forbes and Rigobon called the reason of transmission mechanism as an interdependence, not the contagion. Other models' findings showed us there was contagion after the financial crises in concerning economies. The results of the tests can differ from each other according to the techniques they use, selected periods and selected variables. In this paper, we talked about four different techniques. But each of these four techniques also has different types in themselves. For example, in regard to the GARCH models, there are GARCH-M, MGARCH, UGARCH, etc. This affects the results of each testing. Moreover, we can say that in literature there was no consensus between economists on the reasons of contagion and how crises spread from one country to another.

\section{REFERENCES}

1. Azad, A. S. M. S. (2009). Efficiency, cointegration and contagion in equity markets: Evidence from China, Japan and South Korea. Asian Economic Journal, 23(1), 93-118. https://doi.org/10.1111/j.1467-8381.2009.02002.x

2. Calvo, S., \& Reinhart, C. (1996). Capital flows to Latin America: Is there evidence of contagion effects? (MPRA Paper No. 7124). Retrieved from https://pdfs.semanticscholar.org/6009/077dd8d2c4e5e31a9e81e 68a43ed297acde2.pdf

3. Caramazza, F., Ricci, K., \& Salgado, R. (2000). Trade and financial contagion in currency crises (IMF Working Paper 2000/55). https://doi.org/10.5089/9781451847611.001

4. Chiang, T. C., Jeon, B. N., \& Li, H. (2007). Dynamic correlation analysis of financial contagion: Evidence from Asian markets. Journal of International Money and Finance, 26(7), 1206-1228. https://doi.org/ 10.1016/j.jimonfin.2007.06.005

5. Cominetta, M. (2016). Financial contagion: A new perspective (and a new test) (European Stability Mechanism Working Paper No. 12). https://doi.org/10.2139/ssrn.3139029 
6. Cont, R., \& Schaanning, E. (2017). Fire sales, indirect contagion and systemic stress testing (Norges Bank Working Paper 02/2017). https://doi.org/10.2139/ssrn.2955646

7. Corsetti, G., Pericoli, M., \& Sbracia, M. (2005). Some contagion, some interdependence: More pitfalls in tests of financial contagion. Journal of International Money and Finance, 24(8), 1177-1199. https://doi.org/ 10.1016/j.jimonfin.2005.08.012

8. Edwards, S. (1998). Interest rate volatility, capital controls and contagion (NBER Working Paper No. 6756). https://doi.org/10.3386/w6756

9. Eichengreen, B., \& Rose, A. K. (1999). Contagious currency crises: Channels of conveyance. In T. Ito and A. O. Krueger (Eds.), Changes in exchange rates in rapidly development countries: Theory, practice, and policy issues (NBER-EASE volume 7) (p. 29-56). University of Chicago Press. Retrieved from https://core.ac.uk/ download/pdf/6704287.pdf

10. Eichengreen, B., Rose, A., \& Wyplosz, C. (1996). Contagious currency crises (NBER Working Paper No. 5681). https://doi.org/10.3386/w5681

11. Fleming, M. J., \& Lopez, J. A. (1999). Heat waves, meteor showers, and trading volume: An analysis of volatility spillovers in the U.S. treasury market (Staff Report No. 82, Federal Reserve Bank of New York). https://doi.org/10.2139/ssrn.173091

12. Forbes, K. J., \& Rigobon, R. (2002). No contagion, only interdependence: Measuring stock market comovements. The Journal of Finance, 57(5), 2223-2261. https://doi.org/10.1111/0022-1082.00494

13. Fratzscher, M. (2002). On currency crises and contagion (Working Paper No. 139). Retrieved from European Central Bank website: https://www.ecb.europa.eu/pub/pdf/scpwps/ecbwp139.pdf?99407b836c15b9fdf6880 cfe916554f9

14. Gentile, M., \& Giordano, L. (2012). Financial contagion during Lehman default and sovereign debt crisis: An empirical analysis on Euro area bond and equity markets (CONSOB Working Paper No. 72). https://doi.org/ $10.2139 /$ ssrn.2194112

15. Glick, R., \& Rose, A. K. (1999). Contagion and trade: Why are currency crises regional? Journal of International Money and Finance, 18(4), 603-617. https://doi.org/10.1016/S0261-5606(99)00023-6

16. Gomez-Puig, M., \& Sosvilla-Rivero, S. (2014). EMU sovereign debt market crisis: Fundamentals-based or pure contagion? (Research Institute of Applied Economics Working Paper No. 2014/02). https://doi.org/ $10.2139 /$ ssrn.2434499

17. Grant, E. (2016). Exposure to international crises: Trade vs. financial contagion (ESRB Working Paper No. 30). Retrieved from https://www.esrb.europa.eu/pub/pdf/wp/esrbwp30.en.pdf?7b7cc950c1a2286d395ed 8489bfde5c7

18. Haile, F., \& Pozo, S. (2008). Currency crisis contagion and the identification of transmission channels. International Review of Economics and Finance, 17(4), 572-588. https://doi.org/10.1016/j.iref.2007.05.005

19. Hamao, Y., Masulis, R. W., \& Ng, V. (1990). Correlations in price changes and volatility across international stock markets. The Review of Financial Studies, 3(2), 281-307. https://doi.org/10.1093/rfs/3.2.281

20. Khalid, A. M., \& Rajaguru, G. (2006). Financial market contagion or spillovers evidence from Asian Crisis using multivariate GARCH approach (GDC Working Paper). Retrieved from http://citeseerx.ist.psu.edu/ viewdoc/download?doi=10.1.1.424.1845\&rep=rep1\&type=pdf

21. King, M. A., \& Wadhwani, S. (1990). Transmission of volatility between stock markets. The Review of Financial Studies, 3(1), 5-33. https://doi.org/10.1093/rfs/3.1.5

22. Kogid, M., Ching, K. S., \& Jusoh, M. (2009). Asian financial crisis: An analysis of the contagion and volatility effects in the case of Malaysia. International Journal of Business and Management, 4(5), 128-138. http://doi.org/10.5539/ijbm.v4n5p128

23. Kruger, M., Osakwe, P. N., \& Page, J. (1998). Fundamentals, contagion and currency crises: An empirical analysis (Working Paper No. 98-10). Retrieved from http://citeseerx.ist.psu.edu/viewdoc/download?doi= 10.1.1.178.9027\&rep=rep1\&type $=$ pdf

24. Kuusk, A., Paas, T., \& Viikmaa, K. (2011). Financial contagion of the 2008 crisis: Is there any evidence of financial contagion from the US to the Baltic States. Eastern Journal of European Studies, 2(2), 61-76. Retrieved from https://ideas.repec.org/a/jes/journl/y2011v2p61-76.html

25. Loretan, M., \& English, W. B. (2000). Evaluating correlation breakdowns during periods of market volatility (International Finance Discussion Paper No. 658, Board of Governors of the Federal Reserve System). https://doi.org/10.2139/ssrn.231857

26. Mohti, W., Dionisio, A., Ferreira, P., \& Vieira, I. (2019). Contagion of the subprime financial crisis on frontier stock markets: A copula analysis. Journal of Economies, 7(1), 7-15. https://doi.org/10.3390/economies7010015

27. Novo, A. A. (2003). Contagious currency crises: A spatial probit approach (Banco De Portugal Economic Research Department Working Paper No. 5-03). Retrieved from https://core.ac.uk/download/pdf/6363196.pdf

28. Sun, T., \& Zhang, X. (2009). Spillovers of the U.S. subprime financial turmoil to mainland China and Hong Kong SAR: Evidence from stock markets (IMF Working Paper No. 09/166). Retrieved from https://www.imf.org/en/ Publications/WP/Issues/2016/12/31/Spillovers-of-the-U-S-23162

29. Zhanyun, W. (2018). Research on the mechanism of the spatial contagion of global financial crises: From the perspective of pure contagion. Chinese Journal of Urban and Environmental Studies, 6(1), 1-16. https://doi.org/ 10.1142/S2345748118500070 